\title{
Penerapan Model Pembelajaran Quantum Teaching dalam Meningkatkan Hasil Belajar IPA Tema Lingkungan Sahabat Kita pada Siswa Kelas V SD Negeri Karangasem 1 Tahun Ajaran 2020/2021
}

\author{
Akbar Maulana Hidayat \\ Universitas Sebelas Maret \\ akbarmaulana1996@gmail.com
}

\section{Article History}

received 30/4/2021

\begin{abstract}
The Application of Quantum Teaching Learning Models in Improving Science Learning Outcomes The Environmental Theme of Our Friends to Class V Students at SD Negeri Karangasem 1. The purpose of this study is to improve science learning outcomes through the application of the Quantum Teaching model to class V students of SD Negeri Karangasem 1 academic year 2020/2021. This research is a classroom action research (CAR) which was carried out for three cycles. The subjects of this study were the fifth grade students of SD Negeri Karangasem 1 for the academic year 2020/2021, totaling 34 people. Data collection techniques used are interviews, observations and tests. The validity of the data using technical triangulation and source triangulation. The results show that the application of the Quantum Teaching model can improve science learning outcomes in fifth grade students of SD Negeri Karangasem 1 for the 2020/2021 academic year.
\end{abstract}

Keywords: Quantum Teaching,science learning outcomes

\begin{abstract}
Abstrak
Penerapan Model Pembelajaran Quantum Teaching dalam Meningkatkan Hasil Belajar IPA Tema Lingkungan Sahabat Kita pada Siswa Kelas V SD Negeri Karangasem 1. Tujuan dari penelitian ini yaitu untuk meningkatkan hasil belajar IPA melui penerapan model Quantum Teaching pada siswa kelas V SD Negeri Karangasem 1 tahun ajaran 2020/2021. Penelitian ini merupakan penelitian tindakan kelas (PTK) yang dilaksanakan selama tiga siklus. Subjek dari penelitian ini adalah siswa kelas V SD Negeri Karangasem 1 tahun ajaran 2020/2021 yang berjumlah 34 orang. Teknik pengumpulan data yang digunakan adalah wawancara, observasi dan tes. Validitas data menggunakan triangulasi teknik dan triangulasi sumber. Hasil penelitian menunjukkan bahwa penerapan model Quantum Teaching dapat meningkatkan hasil belajar IPA pada siswa kelas V SD Negeri Karangasem 1 tahun ajaran 2020/2021.
\end{abstract}

Kata kunci: Quantum Teaching, hasil belajar IPA 


\section{PENDAHULUAN}

Pada abad 21 pendidikan menjadi fokus utama dalam upaya menjamin kualitas siswa yang memiliki kecakapan dan keterampilan. Upaya untuk meningkatkan kualitas sumber daya manusia dapat melalui pendidikan. Hal itu sejalan dengan fungsi dan tujuan pendidikan nasional, menurut UU No. 20 tahun 2003, Pasal 3 Tentang Sistem Pendidikan Nasional yaitu bahwa pendidikan nasional berfungsi mengembangkan kemampuan dan membentuk watak serta peradaban bangsa yang bermartabat dalam rangka mencerdaskan kehidupan bangsa. Kompetensi abad 21 merupakan kompetensi utama yang harus dimiliki siswa agar mampu berkiprah dalam kehidupan nyata. Menurut Kemendikbud (2017: 5) kompetensi abad 21 yang harus dimiliki siswa biasa dikenal dengan 4C yaitu: kreativitas dan inovasi (creativity and innovation), berpikir kritis dan pemecahan masalah (critical thinking and problem solving), komunikasi (communication), dan kolaborasi (collaboration). Kaitannya dengan kompetensi abad 21, pembelajaran IPA di SD seyogyanya dilaksanakan dengan memberi kesempatan bagi siswa untuk berkembang, sehingga mereka turut berperan aktif selama kegiatan belajar berlangsung. Pembelajaran IPA diterapkan melalui pemberian pengalaman secara langsung melalui langkah metode ilmiah, cara berpikir, proses inkuiri, discovery, melakukan eksperimen, dan penggunaan pengetahuan dalam memecahkan masalah dalam kehidupan sehari-hari (Leduox, 2002: 34). IImu Pengetahuan Alam (IPA) dalam PP RI Nomor 32 Tahun 2013 pasal 771 merupakan suatu muatan dalam struktur kurikulum yang sejajar dengan pendidikan agama, pendidikan kewarganegaraan, bahasa, matematika, IPS, seni budaya, pendidikan jasmani olahraga, keterampilan/ kejuruan, dan muatan lokal. Hal ini diperkuat oleh Samatowa (2006: 3) yang menjelaskan bahwa IPA adalah ilmu pengetahuan yang mempelajari peristiwa-peristiwa yang terjadi di alam ini.

Berdasarkan hasil wawancara dengan guru kelas V di SDN Karangasem 1 menunjukkan kondisi sebagai berikut: (1) penyampaian materi pembelajaran kepada siswa berpusat pada guru (teacher center) sehingga siswa kurang berpartisipasi dalam kegiatan pembelajaran, terlihat ketika guru hanya menggunakan metode ceramah; (2) siswa kurang kondusif pada saat mengikuti proses pembelajaran, terlihat ketika kegiatan pembelajaran siswa bermain dengan teman sebangku; dan (3) kurangnya pemahaman siswa tentang beberapa materi pelajaran, terlihat ketika peneliti bertanya kepada beberapa siswa tentang materi yang telah dipelajari, siswa kurang menguasai materi. Kondisi tersebut, menyebabkan rendahnya hasil belajar siswa yang dapat dilihat dari Penilaian Akhir Semester (PAS) IPA Kelas V SDN Karangasem 1 Tahun Ajaran 2020/2021.

Apabila permasalahan itu dibiarkan, maka akan berdampak buruk pada kegiatan pembelajaran IPA. Adapun pemecahan masalah ini adalah salah satunya penggunaan metode Quantum Teaching untuk meningkatkan hasil belajar IPA. Berdasarkan pemaparan teori dan kenyataan di lapangan, peneliti tertarik untuk melakukan penelitian dengan harapan dapat meningkatkan hasil belajar IPA materi lingkungan sahabat kita di kelas V SDN Karangasem 1. Untuk mengetahui hasil penerapan model tersebut, maka peneliti melakukan penelitian kolaboratif dengan guru kelas $\mathrm{V}$ SDN Karangasem 1 berjudul "Penerapan Model Pembelajaran Quantum Teaching dalam peningkatan hasil belajar IPA Tema Lingkungan Sahabat Kita pada Siswa Kelas V SDN Karangasem 1 Tahun Ajaran 2020/2021".

\section{METODE}

Penelitian ini merupakan penelitian tindakan kelas (PTK) yang dilaksanakan dalam tiga siklus. Menurut Widayati (2008) menyatakan bahwa penelitian tindakan kelas adalah suatu kegiatan penelitian yang berkonteks kelas yang dilaksanakan untuk memecahkan masalah-masalah pembelajaran yang dihadapi oleh guru, memperbaiki mutu dan hasil pembelajaran dan mencobakan hal-hal baru dalam pembelajaran demi 
peningkatan mutu dan hasil pembelajaran. Penelitian ini menggunakan prosedur penelitian yang setiap siklusnya terdiri dari tahap perencanaan, pelaksanaan, pengamatan, dan refleksi.Setiap siklus terdiri dari empat tahap yaitu: perencanaan, pelaksanaan, pengamatan, dan refleksi. Subjek dalam penelitian ini adalah siswa kelas V SDN Karangasem 1 yang berjumlah 34 siswa. Data yang digunakan adalah data kuantitatif berupa nilai evaluasi hasil belajar IPA dan data kualitatif berupa hasil observasi dan wawancara. Teknik pengumpulan data menggunakan teknik non tes berupa observasi, wawancara dan studi dokumen, dan teknik tes berupa tes evaluasi IPA. Validitas data menggunakan triangulasi teknik dan sumber. Analisis data meliputi reduksi data, penyajian data, dan penarikan kesimpulan. Indikator kinerja penelitian ini adalah peningkatan pembelajaran IPA dengan target $85 \%$ dan ketuntasan minimal siswa dengan target $85 \%$.

\section{HASIL DAN PEMBAHASAN}

Penerapan model pembelajaran Quantum Teaching dalam meningkatkan hasil belajar IPA dilakukan dalam tiga siklus, tiap siklus dilakukan satu kali pertemuan. Suryani (2013: 55) menyatakan bahwa "Quantum Teaching is a learning process by providing backgrounds and strategies to improve the learning teaching process and to make such process more enjoyable". Dapat diartikan bahwa Quantum Teaching adalah proses pembelajaran dengan menyediakan dasar (konsep) dan strategi untuk meningkatkan pembelajaran proses mengajar dan membuat proses tersebut lebih menyenangkan.

Penelitian dilakukan dengan menerapkan langkah model pembelajaran Quantum Teaching. Langkah-langkah model Quantum Teaching juga dijelaskan oleh DePorter, Reardon, dan Nouire (2011: 39-40) mengenai TANDUR dan maknanya yaitu: (1) Tumbuhkan, (2) Alami, (3) Namai, (4) Demonstrasikan, (5) Ulangi, dan (6) Rayakan. Dalam peneltiannya, Yahya (2017: 159) mengungkapkan bahwa kerangka rancangan Quantum Teaching yaitu TANDUR, adalah singkatan dari Tumbuhkan, Alami, Nami, Demonstrasi, Ulangi dan rayakan diterapkan dalam langkah-langkah pembelajaran.

Hasil rekapitulasi data penelitian tindakan kelas ini menunjukkan adanya peningkatan hasil belajar IPA pada siklus I, siklus II dan siklus III. Hasil pengamatan pelaksanaan pembelajaran IPA dengan menerapkan model pembelajaran Quantum Teaching mengalami peningkatan pada siklusnya yaitu:

Tabel 1. Hasil Pengamatan Penerapan Model Pembelajaran Quantum Teaching.

\begin{tabular}{lccc}
\hline \multirow{2}{*}{ Sumber data } & \multicolumn{3}{c}{ Siklus } \\
\cline { 2 - 4 } & I & II & III \\
\hline Guru (\%) & $81,60 \%$ & $85,76 \%$ & $87,50 \%$ \\
Siswa (\%) & $82,29 \%$ & $84,72 \%$ & $88,54 \%$ \\
\hline
\end{tabular}

Berdasarkan tabel di atas, obsevasi terhadap guru pada siklus I persentase $81,60 \%$ dan pada siklus II meningkat menjadi $85,76 \%$. Antara siklus I dan siklus II meningkat sebesar $4,16 \%$. Pada siklus III meningkat $1,74 \%$ menjadi $87,50 \%$. Observasi terhadap siswa pada siklus I persentase mencapai $82,29 \%$ dan pada siklus II meningkat menjadi $84,72 \%$. Antara siklus I dan siklus II meningkat sebesar $2,43 \%$. Pada siklus III meningkat 3,82\% menjadi 88,54\%. Dapat disimpulkan bahwa setiap siklus mengalami peningkatan, berarti langkah Quantum Teaching setiap siklus meningkat.

Sementara data hasil belajar siswa diperoleh dari tes hasil evaluasi yang dilakukan pada setiap akhir pembelajaran pada siklus I, II dan III. Analisis perbandingan hasil belajar yang diperoleh siswa pada siklus I, II dan III termuat dalam tabel berikut: 
Tabel 2. Analisis Hasil Belajar IPA

\begin{tabular}{lccc}
\hline & \multicolumn{3}{c}{ Siklus } \\
\cline { 2 - 4 } & I & II & III \\
\hline Rata rata & 79,12 & 83,82 & 86,47 \\
Siswa tuntas & $62 \%$ & $79 \%$ & $88 \%$ \\
Siswa belum tuntas & $38 \%$ & $21 \%$ & $12 \%$ \\
\hline
\end{tabular}

Berdasarkan tabel di atas, rata rata nilai tes evaluasi hasil belajar IPA kelas $\mathrm{V}$ pada siklus I sebesar 79,12, dan pada siklus II meningkat sebesar 83,82 . Antara siklus I dan siklus II meningkat sebesar 4,7. Pada siklus III meningkat sebesar 2,65 menjadi 86,47 . Persentase ketuntasan pada siklus I sebesar $62 \%$, dan pada siklus II meningkat sebesar $79 \%$. Antara siklus I dan siklus II meningkat sebesar 17\%. Pada siklus III meningkat sebesar $9 \%$ menjadi sebesar $88 \%$.

Dalam pelaksanaan pembelajaran siklus I ditemukan kendala antara lain: (1) guru kurang memberikan motivasi terhadap siswa untuk menghargai pendapat teman yang sedang presentasi, (2) peserta didik belum aktif menanyakan materi yang belum dipahami, (3) guru belum menjelaskan cara menggunakan google form, dan (4) guru memberikan waktu untuk peserta didik mengerjakan tugas. Adapun solusinya yaitu (1) guru memberikan tepuk tangan setiap ada peserta didik yang melakukan sesuatu yang diperintahkan guru, (2) guru menanyakan apakah materi yang disampaikan sudah jelas, serta mendorong siswa untuk percaya diri mengeumkakan pendapatnya, dan (3) guru menjelaskan cara menggunakan google form, dan (4) Guru memberikan tenggan waktu yang lebih lama, agar hasil pekerjaan peserta didik lebih maksimal. Dalam pembelajaran siklus II ditemukan kendala yaitu peserta didik kurang aktif dalam menyimpulkan pembelajaran. Adapun solusinya adalah guru memberikan kesempatan pada peserta didik tertentu untuk menyimpulkan kegiatan pembelajaran yang ia dapat hari itu.

\section{SIMPULAN}

Berdasarkan rumusan masalah, hasil peneltian dan hasil pembahasan dalam penelitian ini, dapat diambil kesimpulan sebagai berikut:

1. Langkah-langkah penerapan model pembelajaran Quantum Teaching dalam meningkatkan hasil belajar IPA tema lingkungan sahabat kita pada siswa kelas V SD Negeri Karangasem 1 tahun ajaran 2020/2021 yang tepat adalah sebagai berikut: (1) tanamkan, (2) alami, (3) namai, (4) demonstrasikan, (5) ulangi dan (6) rayakan.

2. Penerapan model Quantum Teaching dapat meningkatkan hasil belajar IPA tema lingkungan sahabat kita pada siswa kelas V SD Negeri Karangasem 1 tahun ajaran 2020/2021 terbukti dengan hasil evaluasi pada siklus I sebesar $62 \%$, siklus II sebesar $79 \%$ dan siklus III sebesar $88 \%$.

3. Kendala dalam menerapkan model pembelajaran Quantum Teaching untuk meningkatkan hasil belajar IPA tema lingkungan sahabat kita pada siswa kelas V SD Negeri Karangasem 1 tahun ajaran 2020/2021 yaitu: (1) guru kurang memberikan motivasi terhadap siswa untuk menghargai pendapat teman yang sedang presentasi, (2) peserta didik belum aktif menanyakan materi yang belum dipahami, (3) guru belum menjelaskan cara menggunakan google form, (4) guru memberikan waktu untuk peserta didik mengerjakan tugas, dan (5) peserta didik kurang aktif dalam menyimpulkan pembelajaran Adapun solusinya yaitu (1) guru memberikan tepuk tangan setiap ada peserta didik yang melakukan sesuatu yang diperintahkan guru, (2) guru menanyakan apakah materi yang disampaikan sudah jelas, serta mendorong siswa untuk percaya diri mengeumkakan pendapatnya, dan (3) guru menjelaskan cara menggunakan google form, dan (4) Guru memberikan tenggan waktu yang lebih lama, agar hasil pekerjaan peserta didik 
lebih maksimal, dan (5) guru memberikan kesempatan pada peserta didik tertentu untuk menyimpulkan kegiatan pembelajaran yang ia dapat hari itu.

\section{DAFTAR PUSTAKA}

DePorter, B., Reardon, M., \& Nourine, S. S. (2014). Quantum Teaching: Mempraktikkan Quantum Learning di Ruang-Ruang Kelas. Bandung: Kaifa.

Ledoux, S. F. (2002). Defining natural sciences. Behaviorology Today, 5(1), 34-36.

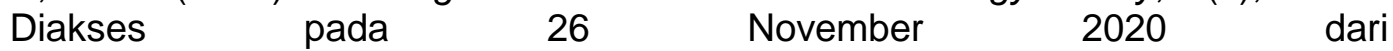
https://behaviorology.org/oldsite/pdf/DefineNatlSciences.pdf

Peraturan Pemerintah Republik Indonesia Nomor 32 Tahun 2013 tentang Perubahan Atas Peraturan Pemerintah Nomor 19 Tahun 2005 tentang Standar Nasional Pendidikan.

Samatowa, U. (2006). Bagaimana Pembelajaran IPA di Sekolah Dasar. Jakarta: Departemen Pendidikan Nasional Direktorat Jenderal Pendidikan Tinggi Direktorat Ketenagaan.

Suryani, N. (2013). Improvement of Students' History Learning Competence through Quantum Learning Model at Senior High School in Karanganyar Regency, Solo, Central Java Province, Indonesia. Journal of Education and Practice. 1 (14), 55. Diakses pada $26 \quad$ November $2020 \quad$ dari https://citeseerx.ist.psu.edu/viewdoc/download?doi=10.1.1.848.5266\&rep=rep1\&t ype $=$ pdf

Widayati. (2008). Penelitian Tindakan Kelas. Jurnal Pendidikan Akuntansi Indonesia. 6 (1). Diakses pada 27 November 2020 dari https://journal.uny.ac.id/index.php/jpakun/article/view/1793

Yahya, H. (2017). Pengaruh Penerapan Model Pembelajaran Quantum Teaching Terhadap Hasil Belajar Biologi Siswa SMA Islam Terpadu Al-Fityan Gowa. Jurnal Biotek, 5(1), 155-166. Diakses pada 26 November 2020 dari http://journal.uinalauddin.ac.id/index.php/biotek/article/view/3455 